\title{
Analisis Kebutuhan Pemanfaatan Video Pembelajaran dalam Meningkatkan Kompetensi Profesional Guru PPKn Sekolah Menengah Atas
}

\author{
Muhammad Japar ${ }^{1}$, Ratna Dyah Suryaratri ${ }^{2}$, Syifa Syarifa ${ }^{3}$, Dini Nur Fadhillah ${ }^{4}$, \\ Djunaidi $^{5}$ \\ ${ }^{1,3}$ Pendidikan Pancasila dan Kewarganegaraan, Fakultas Ilmu Sosial, Universitas Negeri Jakarta \\ ${ }^{2}$ Psikologi, Fakultas Pendidikan Psikologi, Universitas Negeri Jakarta \\ ${ }^{4}$ Pendidikan Kewarganegaraan, Fakultas Keguruan dan Ilmu Pendidikan, Universitas Sebelas Maret \\ ${ }^{5}$ Pendidikan Sejarah, Fakultas Ilmu Sosial, Universitas Negeri Jakarta. \\ Email corresponding authors: mjapar@unj.ac.id
}

\begin{abstract}
This article discusses efforts to improve the competence of Civics teachers in making learning video through a training. Learning video is one form of using technology that must be owned by teachers, especially Civics teachers in order to support the successful implementation of effective and efficient Distance Learning. This is because the Civics Education material tends to be textual, so a media that is able to increase students' attention and interest in learning is needed. The method used is descriptive qualitative method with qualitative data analysis techniques. Data were obtained from observations and questionnaires distributed to 237 training participants who are Civics Education teachers in various schools in Indonesia. Based on the data obtained, this training can be said to be successful. This can be seen from the increase in competence obtained and the positive response from the participants.
\end{abstract}

Keywords: Competence, Teacher, PPKn, Learning Video

\begin{abstract}
ABSTRAK
Artikel ini menganalisis kebutuhan guru PPKn sebagai upaya meningkatkan kompetensi profesional dalam memanfaatkan teknologi dan informasi melalui video pembelajaran. Video pembelajaran menjadi salah satu bentuk pemanfaatan teknologi yang harus dimiliki guru terutama guru PPKn dalam rangka mendukung suksesnya pelaksanaan Pembelajaran Jarak Jauh (PJJ) yang efektif dan efisien. Hal ini dikarenakan materi PPKn yang cenderung tekstual sehingga diperlukan media yang mampu meningkatkan perhatian dan minat belajar peserta didik. Metode yang digunakan adalah metode kualitatif deskriptif dengan teknik analisis data kualitatif. Data diperoleh dari hasil pengamatan dan kuesioner yang disebar kepada 116 guru PPKn SMA di berbagai sekolah yang ada di Indonesia. Berdasarkan data yang diperoleh, hasil penelitian ini menunjukkan bahwa sebesar $80 \%$ guru mengalami kesulitan untuk melibatkan peserta didik aktif dalam kegiatan PJJ. Selain itu, 78\% guru mengalami kesulitan dalam membuat media pembelajaran untuk kegiatan PJJ. Sehingga, kebutuhan yang diperlukan oleh guru adalah pelatihan pemanfaatan video pembelajaran.
\end{abstract}

Kata Kunci: Kompetensi, Guru, PPKn, Video Pembelajaran

\section{PENDAHULUAN}

Pendidikan Pancasila dan Kewarganegaraan adalah pendidikan yang bertujuan untuk membentuk warga negara yang ideal, cerdas hukum, paham akan hak dan kewajibannya serta 
bersikap dan berperilaku sesuai dengan nilai-nilai Pancasila dan UUD 1945. Pendidikan Kewarganegaraan berfokus pada pembentukan diri yang beragam dari segi agama, sosial budaya, bahasa dan suku bangsa untuk menjadi warga negara yang cerdas, terampil, dan berkarakter sebagaimana yang diamanatkan oleh Pancasila dan UUD 1945(Ardiansyah et al., 2019). Sementara itu, Pasal 39 Ayat 2 Undang-Undang Nomor 20 Tahun 2003 tentang Sistem Pendidikan Nasional, menjelaskan bahwa Pendidikan Kewarganegaraan merupakan usaha untuk membekali peserta didik dengan pengetahuan dan kemampuan dasar berkenaan dengan hubungan warga negara serta pendidikan pendahuluan bela negara agar menjadi warga negara yang dapat diandalkan oleh bangsa negara (Depdikbud, 2003). Tujuan pendidikan kewarganegaraan adalah mempersiapkan peserta didik untuk menjadi warga negara yang baik dan cerdas (good and smart citizens) yang berkomitmen kuat dalam mempertahankan kebhinekaan dan integritas nasional di Indonesia (Nurmalisa et al., 2020). Dengan demikian, Pendidikan Kewarganegaraan memiliki andil yang sangat besar dalam membentuk kepribadian warga negara yang cerdas (Nusarastriya, 2013).

Akan tetapi dalam pelaksanaannya, Pendidikan Pancasila dan Kewarganegaraan (PPKn) kurang diminati karena dianggap monoton, membosankan serta menjenuhkan bagi peserta didik. Hal ini bisa disebabkan materi pembelajaran PPKn yang cenderung tekstual tetapi tidak didukung dengan media pembelajaran yang tepat dan menarik. Apalagi pelaksanaan pembelajaran saat ini dilaksakan secara daring sebagai dampak dari adanya pandemi Coronavirus Disease 2019 (Covid-19). Keadaan ini mengharuskan pembelajaran yang biasanya dilaksanakan secara tatap muka beralih ke Pembelajaran Jarak Jauh (PJJ). Tentunya, pelaksanaan PJJ tidak berjalan mulus begitu saja, terdapat berbagai kendala yang dihadapi baik oleh guru maupun peserta didik. Selain masalah sarana dan prasarana yang belum memadai, kompetensi guru juga menjadi salah satu yang perlu diperhatikan. Kompetensi guru dapat diapahami sebagai kebulatan pengetahuan, keterampilan dan sikap yang nampak dari perilaku cerdas dan penuh tanggung jawab seorang guru dalam menjalankan profesinya (Novauli, 2015). Salah satu kompetensi yang harus dimiliki seorang guru yaitu pengetahuan dan keterampilan dalam menggunakan teknologi sebagai media pembelajaran. Penggunaan teknologi dalam kegiatan pembelajaran memiliki peran penting dalam meningkatkan kualitas pembelajaran yang lebih efektif dan efisien(Japar et al., 2020). Kompetensi ini perlu dimiliki setiap guru terutama di masa pandemi yang mau tidak mau harus mengandalkan penggunaan teknologi dalam mendukung pelaksanaan PJJ.

Salah satu contoh penggunaan teknologi dalam pembelajaran adalah penggunaan media pembelajaran audio visual. Selain dapat memotivasi peserta didik, penggunaan media audio visual sangat berpengaruh terhadap tercapainya tujuan pembelajaran(Ananda, 2017). Video menjadi salah satu jenis media pembelajaran audio visual yang dapat merangsang fungsi indera pendengaran dan indera penglihatan(Turyati et al., 2016). Media video dapat menvisualisasikan materi pembelajaran dan pesan-pesan yang hendak disampaikan kepada peserta didik(Agustiningsih, 2015). Selain mampu mengombinasikan visual dengan audio, juga dapat dikemas dengan menggabungkan antara komunikasi tatap muka dengan komunikasi kelompok dengan menggunakan teks, audio dan musik (Yudianto, 2017). Penggunaan video dalam pembelajaran PPKn dapat memberikan pemahaman yang lebih baik kepada peserta didik apabila dapat dikemas dengan menarik. Selain itu, pemanfaatan video pembelajaran sebagai media pembelajaran dapat dikatakan efektif dan efisien karena pemanfaatannya tidak terbatas ruang dan waktu serta dapat dimanfaatkan dalam pelaksanaan Pembelajaran Jarak Jauh (PJJ).

Adapun software yang dapat dimanfaatkan guru dalam membuat video pembelajaran adalah Animaker, yaitu perangkat lunak yang memungkinkan seseorang dapat membuat animasi dengan mudah dan menarik. Animaker menyediakan beragam karakter animasi, efek, transisi, background, dan elemen-elemen yang dapat digunakan dalam membuat animasi secara 
professional. Selain menggunakan asset yang telah disediakan, Animaker juga menyediakan fitur yang memungkinkan pengguna untuk dapat menggunakan asset yang telah dibuat sendiri (Kurniawati et al., 2020). Hal tersebut membuat pengguna juga dapat berkreasi lebih luas dan menyisipkan hasil karyanya sendiri atau tanda khusus pada video animasi yang dibuat. Animaker dapat membantu guru PPKn dalam mengemas materi dalam bentuk video pembelajaran berbasis animasi yang dapat dimanfaatkan selama PJJ. Video pembelajaran berbasis animasi dapat memberi dopamin atau hormon rasa senang pada peserta didik sekaligus mengasah keterampilan guru dalam penguasaan teknologi (Fajarwati \& Irianto, 2021).

Penelitian terkait pemanfaatan video dalam pembelajaran pernah dilakukan oleh Busyaeri, Udin dan Zaennudin (2016), hasil penelitiannya menunjukkan bahwa terdapat pengaruh penggunaan video pembelajaran dalam meningkatkan minat dan hasil belajar siswa di MIN Kroya Cirebon. Selanjutnya penelitian yang dilakukan Agustiningsih (2015), menunjukkan bahwa terdapat pengaruh yang signifikan dari penerapan video terhadap hasil belajar siswa sehingga video dapat menjadi media pembelajaran alternatif dalam mendukung keberhasilan diterapkannya Kurikulum 2013. Penelitian yang dilakukan Andari (2019) juga menunjukkan bahwa media pembelajaran berbasis video sangat efektif karena dapat menggugah semangat belajar peserta didik. Selain itu, Kurniwati, et al. (2020) dalam penelitiannya menunjukkan bahwa Animaker dapat dimanfaatlan sebagai tools menarik bagi guru untuk membuat media pembelajaran. Namun, hal ini menjadi tantangan tersendiri bagi guru PPKn. Berdasarkan hasil penelitian Sakman, dan Ara (2020) menunjukkan bahwa pembelajaran yang dilakukan untuk meningkatkan partisipasi belajar peserta didik melalui video YouTube. Tetapi, guru tidak dapat meningkatkan kompetensi profesionalnya dalam memanfaatkan teknologi dan informasi. Hal ini dikarenakan media yang digunakan sudah tersedia di YouTube. Sehingga, media yang ada masih belum sesuai dengan kebutuhan peserta didik. Hasil penelitian Prijanto (2017) menyarankan agar guru memberikan penugasan kepada peserta didik untuk membuat film dalam bentuk video yang kemudian di upload ke YouTube. Dengan begitu diharapkan kegiatan tersebut dapat membuat peserta didik tertarik untuk pembelajaran PPKn. Hanya saja guru tidak diberikan kesempatan untuk meningkatkan kompetensi profesionalnya dalam proses pembelajaran. Terlebih, dengan pandemic Covid-19 guru PPKn menghadapi PJJ tanpa ada persiapan sebelumnya. Kegiatan PJJ yang sudah berlangsung satu tahun, menunjukkan tidak adanya perubahan yang signifikan pada hasil belajar peserta didik. Berdasarkan hasil penelitian Cahyani, Listiana dan Larasati (2020) menunjukkan bahwa 52.6\% peserta didik mengalami penurunan motivasi belajar selama PJJ. Oleh sebab itu, guru juga perlu meningkatkan kompetensi agar dapat meningkatkan motivasi belajar peserta didik. Sehingga, penelitian ini bertujuan untuk menganalisis kebutuhan pemanfaatan video pembelajaran dalam meningkatkan kompetensi professional guru PPKn.

\section{METODE}

Dalam melakukan analisis kebutuhan pemanfaatan video pembelajaran, metode penelitian yang digunakan adalah penelitian survei. Survei dilakukan untuk memecahkan masalah baik dengan isu skala besar maupun skala kecil. Sehingga, dari hasil survey yang dilakukan diketahui terkait kebutuhan guru dalam memanfaatkan video pembelajaran. Hal ini dikarenakan penelitian survei adalah pendekatan yang berguna dan sah untuk penelitian yang memiliki manfaat yang jelas dalam membantu untuk menggambarkan dan mengeksplorasi variabel dan konstruksi yang menarik.Penelitian survei didefinisikan sebagai pengumpulan informasi dari sampel individu melalui tanggapan mereka terhadap pertanyaan(Ponto, 2015). Jenis penelitian ini memungkinkan berbagai metode untuk merekrut peserta, mengumpulkan 
data, dan memanfaatkan berbagai metode instrumentasi. Karena penelitian ini dapat menggunakan strategi kuantitatif dan kualitatif, berdasarkan tujuan penelitian peneliti menggunakan keduanya atau yang lebih dikenal strategi metode campuran(Sugiyono, 2014). Tujuan dari strategi pengambilan sampel dalam penelitian survei adalah untuk mendapatkan sampel yang cukup yang mewakili populasi yang diinginkan. Karenanya, sebagian dari sampel yang digunakan untuk memperkirakan respons populasi. Sehingga, penting untuk mengidentifikasi populasi yang diinginkan dengan benar dan sampel idealnya mencakup individu yang mencerminkan populasi yang dituju dalam hal karakteristik populasi. Oleh karena itu peneliti tertarik pada populasi guru PPKn SMA. Peneliti memperoleh sampel guru PPKn SMA dari empat provinsi di Indonesia yaitu DKI Jakarta, Banten, Jawa Timur, dan Jawa Barat. Hal ini dikarenakan keempat daerah tersebut dapat mempengaruhi kecukupan dan keterwakilan sampel yang diperoleh. Oleh sebab itu, Teknik pengambilan sampe yang digunakan adalah purposive sampling. Peneliti menggunakan sampel sesuai dengan tujuan dari penelitian. Mengingat, penelitian ini memiliki focus menganalisis kebutuhan pemanfaatan video pembelajaran dalam meningkatkan kompetensi guru. Peneliti mengambil data hanya pada guru PPKn SMA. Jumlah dari sampel dalam penelitian ini adalah 116 guru PPKn SMA.

\section{Pengumpulan Data}

Penelitian survei dapat menggunakan berbagai metode pengumpulan data dengan yang paling umum adalah kuesioner dan wawancara. Kuesioner dikelola oleh peneliti dan diberikan secara individu kepada guru PPKn SMA mencakup serangkaian item yang mencerminkan tujuan penelitian. Kuesioner mencakup pertanyaan demografis dan instrumen penelitian yang valid dan andal(Costanzo et al., 2012). Kuesioner disebarkan kepada 116 guru PPKn SMA melalui google form. Dari hasil kuesioner, peneliti memilih secara acak guru PPKn SMA untuk dilakukan wawancara. Oleh karena itu, peneliti melakukan wawancara kepada sepuluh guru PPKn SMA. Wawancara dilakukan secara terbuka tetapi melalui aplikasi zoom. Peneliti melakukan wawancara selama 45 menit dengan pertanyaan semi-terstruktur.

\section{Instrumen Survei}

Survei yang dilakukan oleh peneliti mencakup banyak pertanyaan inti yang dirancang untuk menganalisis kebutuhan guru PPKn SMA terkait pemanfaatan video pembelajaran. Instrumen mencakup pembelajaran aktratif, media pembelajaran yang digunakan pada saat PJJ, kendala yang dihadapi selama kegiatan PJJ, kebutuhan pemanfaatan video pembelajaran, video pembelajaran yang pernah digunakan, dan kendala yang ditemui pada saat proses pembuatan video pembelajaran. Kategori respons yang digunakan dalam pertanyaan tertutup ini adalah "Ya" dan "Tidak". Kecuali dinyatakan lain dalam teks, kata-kata dari pertanyaan survei individual ditampilkan dalam tabel dan gambar yang disajikan di bagian hasil.

\section{Analisis Data}

Semua survei tunduk pada kesalahan, termasuk kesalahan pengambilan sampel, format kuesioner, kata-kata pertanyaan, cakupan sampel, efek respons karena survei, dan faktor lainnya. Dengan demikian, hasil mungkin berbeda dari apa yang akan diperoleh jika seluruh populasi guru PPKn SMA telah disurvei. Kesalahan pengambilan sampel bervariasi dengan ukuran sampel dan ukuran kelompok responden dalam sampel. Kemungkinan sumber kesalahan non-sampling termasuk bias, kata-kata pertanyaan, dan efek pengurutan. Upaya untuk meminimalkan kesalahan non-sampling termasuk pra-pengujian semua instrument dilakukan untuk memeriksa konsistensi dan keandalan internal. Selanjutnya review setiap instrumen oleh beberapa ahli, dan penggunaan instrumen serta pertanyaan diuji sebelumnya. 


\section{HASIL DAN PEMBAHASAN}

Mata Pelajaran PPKn menitikberatkan pada pembentukan warga negara yang memahami dan mampu melaksanakan hak dan kewajibannya untuk menjadi warga negara Indonesia yang cerdas, terampil, dan berkarakter yang diamanatkan oleh Pancasila dan UUD 1945. Oleh karena itu, guru PPKn memiliki tantangan agar peserta didik menyukai dan lebih termotivasi dalam mengikuti pembelajaran PPKn. Hasil penelitian Syaparuddin dan Elihami (2020) menunjukkan bahwa manfaat dari penelitian ini adalah memberikan masukan untuk meningkatkan motivasi belajar peserta didik melalui penggunaan media video, sehingga dapat dijadikan sebagai bahan pertimbangan dalam penggunaan media pembelajaran. Namun, tidak semua guru mampu memanfaatkan video pembelajaran. Untuk mengetahui kebutuhan tersebut, analisis diperlukan dalam pengembangan video pembelajaran. Tabel 1 menunjukkan karakteristik sampel guru PPKn SMA, sebagai berikut:

Tabel 1. Karakteristik Guru PPKn SMA

\begin{tabular}{lcc}
\hline \multicolumn{1}{c}{ Aspek Demografi } & Frekuensi & Presentase \\
\hline Jenis Kelamin & & \\
Laki-Laki & 47 & $40.5 \%$ \\
Perempuan & 69 & $59.5 \%$ \\
Usia & & \\
< 35 Tahun & 45 & $38.8 \%$ \\
35 - 50 Tahun & 42 & $36.2 \%$ \\
> 50 Tahun & 29 & $25 \%$ \\
Asal Provinsi & & \\
DKI Jakarta & 29 & $25 \%$ \\
Jawa Barat & 29 & $25 \%$ \\
Jawa Timur & 29 & $25 \%$ \\
Banten & 29 & $25 \%$ \\
\hline
\end{tabular}

Berdarakan tabel 1 menunjukkan bahwa 59.5\% responden yang melakukan pengisian survey adalah perempuan. Data tersebut menggambarkan bahwa jumlah guru perempuan jauh lebih banyak daripada laki-laki. Disamping itu, usia responden dengan rentan kurang dari 35 tahun sebesar $38.8 \%$. Hal ini menunjukkan bahwa guru muda dan produktif jauh lebih banyak dibandingkan usia 35-50 dan diatas 50 tahun. Meskipun memang masih ada guru yang berusia diatas 50 tahun. Sehingga tidak dipungkiri mereka mengalami kesulitan dalam pembuatan media pembelajaran. Dengan kata lain guru PPKn SMA dengan rentang usia diatas 50 tahun merupakan generasi X. Sedangkan guru dengan rentang usia dibawah 35 tahun masuk ke dalam generasi milenial. Menurut Silviana dan Darmawan (2018) generasi milenial dikatakan mahir dalam teknologi. Oleh sebab itu, karakteristik dapat menjadi dasar kebutuhan pemanfaatan video pembelajaran guru PPKn SMA. 
Tabel 2. Pandangan Guru terkait Kegiatan PJJ

\begin{tabular}{ccccc}
\hline No & \multicolumn{1}{c}{ Aspek } & \multicolumn{2}{c}{ Frekuensi } & \multicolumn{2}{c}{ Presentase } \\
\hline $\begin{array}{c}\text { Kendala dalam Kegiatan PJJ } \\
1 \quad \begin{array}{l}\text { Guru mengalami kesulitan untuk } \\
\text { melibatkan peserta didik aktif dalam } \\
\text { kegiatan PJJ }\end{array}\end{array}$ & 93 & 23 & $80 \%$ & $20 \%$ \\
$2 \quad \begin{array}{l}\text { Guru mengalami kesulitan dalam } \\
\text { membuat media pembelajaran untuk } \\
\text { kegiatan PJJ }\end{array}$ & 89 & 27 & $78 \%$ & $22 \%$ \\
$\begin{array}{l}\text { Media Pembelajaran pada Kegiatan PJJ } \\
1 \quad \begin{array}{l}\text { Guru pernah menggunakan video } \\
\text { pembelajaran sebagai media }\end{array}\end{array}$ & 46 & 70 & $34 \%$ & $66 \%$ \\
$\quad \begin{array}{l}\text { pembelajaran } \\
\text { Guru pernah mengikuti pelatihan } \\
\text { pembuatan video pembelajaran }\end{array}$ & 28 & 88 & $24 \%$ & $76 \%$ \\
\hline
\end{tabular}

Tabel 2 menunjukkan bahwa 80\% guru mengalami kesulitan untuk melibatkan peserta didik aktif dalam kegiatan PJJ. Hal ini dikarenakan guru tidak dapat mengontrol peserta didik secara langsung. Terlebih, proses pembelajaran yang dilakukan melalui daring ini membuat guru kesulitan dalam berinteraksi dengan peserta didik. Menurut Churiyah, et al. (2020) guru kesulitan menemukan alat yang tepat untuk mempraktikkan PJJ. Selain itu, peserta didik kurang mampu beradaptasi dengan media pembelajaran yang dipilih guru. Sehingga, mereka mengalami kesulitan dalam mengelola kegiatan belajar mengajar dari rumah(Pakpahan \& Fitriani, 2020). Perubahan proses pembelajaran dari tradisional ke konvensional tanpa adanya persiapan membuat guru merasa sulit dalam membuat media pembelajaran. Kesulitan tersebut mencapai $78 \%$. Secara umum, peneliti menemukan bahwa sekolah-sekolah di daerah perkotaan memanfaatkan situs pendidikan seperti Google Classroom, Edmodo, Schoology dan aplikasi pintar untuk belajar. Sedangkan yang terjadi di sekolah-sekolah di pedesaan, guru cenderung memilih cara yang paling mudah diakses oleh peserta didik yaitu WhatsApp(Kusuma \& Hamidah, 2020).

Meskipun beberapa penelitian sebelumnya mengembangkan video pembelajaran untuk media pembelajaran PJJ(Dwiyogo, 2014;Sakman \& Ara, 2020), tetapi masih ada 66\% yang belum menggunakannya. Selain itu, hanya $28 \%$ guru yang pernah mengikuti pelatihan pembuatan video pembelajaran. Melihat kondisi ini, pelatihan sangat dibutuhkan oleh guru untuk mengembangkan kompetensi professional mereka. Menurut Ammy dan Wahyuni (2020)PJJ tidak disukai peserta didik karena mereka kurang memahami materi yang dijelaskan oleh guru. Hal ini dikarenakan kendala yang sering dialami khususnya pada sinyal internet. Sehingga, salah satu alternatif yang dapat diberikan adalah melalui video pembelajaran. Model pembelajaran online di situasi Pandemi Covid-19 ini memang sangat wajib, hal ini bertujuan untuk meminimalisir penyebaran virus yang semakin meluas ini. Guru sebagai fasilitator utama proses belajar mengajar kegiatan, dalam menghadapi hal seperti ini tentunya juga akan mengubah model pembelajaran yang biasanya diterapkan di kelas menjadi pembelajaran online. Berdasarkan pelaksanaan wawancara mendalam peneliti dengan guru, ada beberapa hal yang disampaikan terkait upaya yang sudah dilakukan untuk mengajak peserta didik aktif dalam kegiatan PJJ. Untuk menjaga kode etik penelitian, nama guru disamarkan dengan guru 1 - guru 10.

"Upaya yang saya lakukan untuk membuat aktif peserta didik pada saat pembelajaran melalui diskusi tanya jawab. Peserta didik juga dilibatkan dalam 
perencanaa, dan cara pembelajaran yang disesuaikan dengan kebutuhan mereka" (Guru 1, 2021).

"Biasanya dalam proses kegiatan PJJ saya selalu memberikan motivasi kepada peserta didik. Selain itu melibatkan peserta didik dalam kegiatan belajar dengan mengajak mereka untuk membuat video kreatif yang diunggah di sosial media" (Guru 3, 2021)

Walaupun dari hasil tabel 2 menunjukkan guru kesulitan untuk melibatkan peserta didik aktif dalam kegiatan PJJ, tetapi mereka tetap berupaya membuat peserta didik menjadi lebih partisipatif. Secara umum, berdasarkan beberapa wawancara yang diberikan peneliti kepada guru, sebenarnya guru tidak terlalu siap untuk model pembelajaran online ini, karena panggilan untuk belajar di rumah juga dilakukan tiba-tiba dan koordinasi terlalu terburu-buru. Sehingga proses pembelajaran melalui sistem online ini memiliki belum dilaksanakan secara optimal.

"Kendala yang sering dihadapi baik guru maupun peserta didik dalam kegiatan PJJ adalah jaringan yang lambat. Selain itu, keterbatasan teknik pembuatan media pembelajaran. Sehingga, media yang diberikan kepada peserta didik kurang begitu menarik dan membuat mereka tidak merespon" (Guru 4, 2021). "Selain sinyal yang kurang baik, kendala yang dihadapi adalah minimnya pengetahuan tentang aplikasi. Kami dituntut untuk membuat media pembelajaran yang kreatif dan inovatif tetapi tidak ada fasilitas yang disediakan secara baik oleh sekolah maupun pemerintah.” (Guru 5, 2021).

Berdasarkan hasil wawancara menunjukkan bahwa guru sering kali dihadapkan pada masalah utama terkait jaringan internet pada kegiatan PJJ. Selain itu, kebutuhan akan fasilitas sangat diperlukan dalam menunjang pembelajaran. Terlebih melihat hasil pada tabel 2 bahwa masih ada $76 \%$ guru yang belum pernah mengikuti kegiatan pelatihan video pembelajaran. Menurut Ardiansyah, Sindu, dan Putrama (2019)video pembelajaran adalah media yang menyajikan audio dan visual yang berisi pesan-pesan pembelajaran baik yang berisi konsep, prinsip, prosedur, teori aplikasi pengetahuan untuk membantu pemahaman terhadap suatu materi pembelajaran. Sehingga, video pembelajaran ini dapat menjadi sarana untuk memberikan informasi pembelajaran. Pemanfaatan ini berhubungan erat dengan kompetensi professional yang harus dimiliki oleh guru PPKn SMA. Hal ini dikarenakan tingkat profesionalisme guru menurut bidangnya dapat berkontribusi dalam meningkatkan prestasi belajar peserta didik. Kompetensi yang berkaitan dengan penguasaan materi pembelajaran yang luas dan mendalam, meliputi penguasaan materi isi kurikulum dan substansi mata pelajaran keilmuan secara filosofis berkontribusi terhadap kinerja guru dalam pembelajaran(Hakim, 2015). Meskipun menurut Busyaeri, Udin dan Zaennudin (2016) terdapat pengaruh yang signifikan terhadap penggunaan video pembelajaran dalam meningkatkan minat dan hasil belajar peserta didik, tetapi hal itu tidak dapat terwujud bila guru masih mengalami kendala. Hal ini menjadi catatan penting bagi dinas Pendidikan untuk dapat membantu guru meningkatkan kompetensi professional khususnya dalam menggunakan teknologi dan informasi pada pembelajaran PPKn. Sejalan dengan Balakrishnan dan Gan Proses pembelajaran melalui media online hendaknya dilakukan dengan tidak membebani peserta didik dan guru. Guru diberikan kebebasan untuk menyiapkan atau memilah sendiri media yang dianggap sesuai dengan kebutuhan pembelajarannya salah satunya video pembelajaran.

\section{KESIMPULAN}

Salah satu kompetensi yang harus dimiliki seorang guru PPKn yaitu pengetahuan dan keterampilan memanfaatkan teknologi dalam pembelajaran. Sebab, pemanfaatan teknologi dapat menciptakan pembelajaran yang efektif dan efisien terutama di masa pandemi Covid-19 
yang mengalihkan pembelajaran tatap muka ke Pembelajaran Jarak Jauh (PJJ). Kondisi ini menuntut guru untuk terus meningkatkan keterampilannya, terutama keterampilan dalam penguasaan teknologi demi mendukung proses pembelajaran. Adapun contoh pemanfaatan teknologi dalam kegiatan pembelajaran yaitu dengan menayangkan video pembelajaran yang dapat merangsang indra penglihatan dan pendengaran serta memberikan rasa senang kepada peserta didik sehingga tidak jenuh selama mengikuti pembelajaran PPKn yang cenderung tekstual. Berdasarkan analisis kebutuhan pemanfaatan video pembelajaran, guru masih membutuhkan pelatihan untuk meningkatkan keterampilannya. Sehingga, penelitian ini kedepannya dapat menjadi dasar bagi peneliti di masa yang akan dating untuk mengembangkan pelatihan video pembelajaran bagi guru PPKn SMA.

\section{DAFTAR PUSTAKA}

Agustiningsih, A. (2015). Video Sebagai Alternatif Media Pembelajaran Dalam Rangka Mendukung Keberhasilan Penerapan Kurikulum 2013 di Sekolah Dasar. PEDAGOGIA: Jurnal Pendidikan, 4(1), 50. https://doi.org/10.21070/pedagogia.v4i1.72

Ammy, P. M., \& Wahyuni, S. (2020). Analisis Motivasi Belajar Mahasiswa Menggunakan Video Pembelajaran sebagai Alternatif Pembelajaran Jarak Jauh (PJJ). Jurnal Matematics Paedagogic, 5(1), 27-35.

Ananda, R. (2017). Penggunaan Media Audio Visual untuk Meningkatkan Hasil Belajar Pendidikan Kewarganegaraan Siswa Kelas IV SD Negeri 016 Bangkinang Kota. Jurnal Basicedu, 1(1), 21-30. https://doi.org/10.31004/basicedu.v1i1.149

Andari, I. Y. (2019). Pentingnya Media Pembelajaran Berbasis Video untuk Siswa Jurusan IPS tingkat SMA se-Banten. Prosiding Seminar Nasional Pendidikan FKIP, 2(1), 263 275. https://jurnal.untirta.ac.id/index.php/psnp/article/download/5765/4138

Ardiansyah, H., Sindu, I. G. P., \& Putrama, I. M. (2019). Pengembangan Video Pembelajaran PPKn Untuk Pengenalan Suku Dan Budaya Indonesia (Studi Kasus : Kelas IV Madrasah Ibtidaiyah Negeri Singaraja). Kumpulan Artikel Mahasiswa Pendidikan Teknik Informatika (KARMAPATI), 8(2), 319. https://doi.org/10.23887/karmapati.v8i2.18386

Busyaeri, A., Udin, T., \& Zaenudin, A. (2016). Pengaruh Penggunaan Video Pembelajaran Terhadap Peningkatan Hasil Belajar Mapel Ipa Di Min Kroya Cirebon. Al Ibtida: Jurnal Pendidikan Guru MI, 3(1), 116-137. https://doi.org/10.24235/al.ibtida.snj.v3i1.584

Cahyani, A., Listiana, I. D., \& Larasati, S. P. D. (2020). Motivasi Belajar Siswa SMA pada Pembelajaran Daring di Masa Pandemi Covid-19. IQ (Ilmu Al-Qur'an): Jurnal Pendidikan Islam, 3(1), 123-140. https://doi.org/10.37542/iq.v3i01.57

Churiyah, M., Sholikhan, S., Filianti, F., \& Sakdiyyah, D. A. (2020). Indonesia Education Readiness Conducting Distance Learning in Covid-19 Pandemic Situation. International Journal of Multicultural and Multireligious Understanding, 7(6), 491.

https://doi.org/10.18415/ijmmu.v7i6.1833

Costanzo, E. S., Stawski, R. S., Ryff, C. D., Coe, C. L., \& Almeida, D. M. (2012). Cancer Survivors' Responses to Daily Stressors: Implications for Quality of Life. Health Psychology, 31(3), 360-370. https://doi.org/10.1037/a0027018.Cancer

Departemen Pendidikan dan Kebudayaan. (2003). Undang-Undang Nomor 20Tahun 2003

Tentang Sistem Pendidikan Nasional.

Dwiyogo, W. (2014). Analisi Kebutuhan Pengembangan Model Rancangan Pembelajaran

Berbasis Blended Learning (PBBL) Untuk Meningkatkan Hasil Belajar Pemecahan Masalah. Jurnal Pendidikan Dan Pembelajaran (JPP), 21(1), 71-78.

Fajarwati, M. I., \& Irianto, S. (2021). Pengembangan Media Animaker Materi Keliling dan Luas Bangun Datar Menggunakan Kalkulator di Kelas IV SD UMP. EL-Muhbib Jurnal 
Pemikiran Dan Penelitian Pendidikan Dasar, 5(1), 1-11.

Hakim, A. (2015). Contribution of Competence Teacher (Pedagogical, Personality,

Professional Competence and Social) On the Performance of Learning. The

International Journal Of Engineering And Science, 4(2), 1-12. www.theijes.com

Japar, M., Irawaty, Syarifa, S., \& Fadhillah, D. N. (2020). Pelatihan Pembuatan Media

Pembelajaran Berbasis ICT Untuk Meningkatkan Kompetensi Guru PPKn SMP. Jurnal

Karya Abdi, 4(2), 264-269.

Kurniawati, A., Siradjuddin, I. A., Sophan, M. K., Sari, A. K., Ningsih, P. R., \& Ramansyah, W. (2020). Pemanfaatan Tools Animasi untuk Media Pembelajaran bagi SMKN 1

Labang Bangkalan Madura. Jurnal Pengabdian Dan Pemberdayaan Masyarakat, 4(2), 317-322.

Kusuma, J. W., \& Hamidah, H. (2020). Perbandingan Hasil Belajar Matematika Dengan

Penggunaan Platform Whatsapp Group Dan Webinar Zoom Dalam Pembelajaran Jarak Jauh Pada Masa Pandemik Covid 19. Jurnal Ilmiah Pendidikan Matematika, 5(1). https://doi.org/10.26877/jipmat.v5i1.5942

Novauli, F. (2015). Kompetensi Guru dalam Peningkatan Prestasi Belajar Pada SMP Negeri

Dalam Banda Aceh. Jurnal Administrasi Pendidikan Banda Aceh, 3(1), 45-67.

Nurmalisa, Y., Mentari, A., \& Rohman, R. (2020). Peranan Pembelajaran Pendidikan

Kewarganegaraan Dalam Membangun Civic Conscience. Bhineka Tunggal Ika: Kajian

Teori Dan Praktik Pendidikan PKn, 7(1), 34-46.

https://doi.org/10.36706/jbti.v7i1.10082

Nusarastriya, Y. H. (2013). Permasalahan dan Tantangan Guru PKn Menghadapi Perubahan Kurikulum (2013). Satya Widya, 29(1), 23.

https://doi.org/10.24246/j.sw.2013.v29.i1.p23-29

Pakpahan, R., \& Fitriani, Y. (2020). Analisa Pemafaatan Teknologi Informasi Dalam

Pemeblajaran Jarak Jauh Di Tengah Pandemi Virus Corona Covid-19. JISAMAR

(Journal of Information System, Applied, Management, Accounting and Researh), 4(2), $30-36$.

Ponto, J. (2015). Understanding and Evaluating Survey Research. Journal of the Advanced Practitioner in Oncology, 6(2), 168-16871.

Prijanto, J. H. (2017). Pemanfaatan Video Dalam Pembelajaran Pancasila Dan

Kewarganegaraan Untuk Meningkatkan Kemampuan Berpikir Kritis Siswa Terhadap

Kebijakan Publik. Jurnal Teori Dan Praksis Pembelajaran IPS, 2(1), 6-14.

https://doi.org/10.17977/um022v2i12017p006

Sakman, \& Ara. (2020). Meningkatkan Partisipasi Belajar Peserta Didik Melalui Penggunaan

Media Video Youtube. Jurnal Pemikiran Dan Penelitian Ilmu-Ilmu Sosial, Hukum, \&

Pengajarannya, 15(1), 28-35.

Silvana, H., \& Darmawan, C. (2018). Pendidikan Literasi Digital Di Kalangan Usia Muda Di

Kota Bandung. Pedagogia, 16(2), 146. https://doi.org/10.17509/pdgia.v16i2.11327

Sugiyono. (2014). Educational Research Methods Quantitative Approach, Qualitative, and

R\&D. Alfabeta.

Syaparuddin, S., \& Elihami, E. (2020). Improving Student Learning Motivation Through the

Utilization of Video Media in Education Students. Jurnal Edukasi Nonformal, 1(2), 228235.

Turyati, Muchtarom, M., \& Winarno. (2016). Pengaruh Penggunaan Media Video Edukasi terhadap Hasil Belajar PKn Siswa Kelas VII SMP Negeri 2 Gondangrejo. PKn

Progresif, 11(1), 256-267.

Yudianto, A. (2017). Penerapan Video Sebagai Media Pembelajaran. Seminar Nasional

Pendidikan 2017, 234-237. 